\title{
Scleredema of Buschke associated with difficult-to-control type 2 diabetes mellitus
}

\author{
Luciana Rodino Lemes ${ }^{1 *}$, Gabriele Medina Vilela ${ }^{1}$, Sandra Maria Barbosa Durães ${ }^{2}$, Enoi Aparecida Guedes Vilar ${ }^{3}$ \\ ${ }^{1}$ Graduate degree in Dermatology from Universidade Federal Fluminense (UFF), Niterói, RJ, Brazil \\ ${ }^{2} \mathrm{PhD}$ in Dermatology from Universidade Federal do Rio de Janeiro (UFRJ). Adjunct Professor IV, Dermatology, UFF, Niterói, RJ, Brazi \\ ${ }^{3}$ MSc in Anatomical Pathology from UFF. Adjunct Professor, Pathology, UFF, Niterói, RJ, Brazil
}

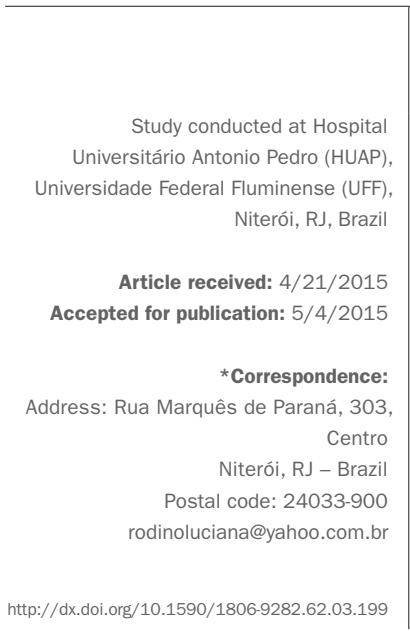

\section{SUMmARY}

Scleredema of Buschke (SB) is a rare disorder of connective tissue characterized by diffuse non-pitting induration of the skin, mainly on the cervical, deltoid and dorsal regions. It is a cutaneous mucinosis of unknown etiology and is associated with bacterial or viral infections, hematological disorders and diabetes mellitus. Histopathological examination shows thickened dermis with wide collagen bundles separated by gaps that correspond to mucopolysaccharide deposits, visualized using special staining. Several treatments are reported in the literature without well-established results. We report a case of SB in a patient with type 2 diabetes mellitus.

Keywords: scleredema adultorum, diabetes mellitus, dorsum.

\section{INTRODUCTION}

Scleredema of Buschke (SB) is a rare disorder of connective tissue, perhaps more prevalent than reported in the literature, characterized by diffuse induration of the skin, especially in the cervical, deltoid and dorsal regions. Systemic manifestations are also described. ${ }^{1}$ It is a cutaneous mucinosis divided into three types according to its associations. Pathogenesis is unknown but triggering factors are described, such as hyperinsulinemia, vascular damage, lymphatic obstruction, and streptococcal hypersensitivity. We report a case of SB in a patient with type 2 diabetes mellitus.

\section{CAse}

Male, 63-year old obese patient, with long-standing difficult-to-control diabetes mellitus, high blood pressure and dyslipidemia; he presented erythema and induration of the neck and upper back starting 1 month earlier (Figure 1). The patient had no clinical history or laboratory findings compatible with any infections or blood disorders. Histopathological examination of the affected area on the back showed: thickened collagen fibers in the reticular dermis with gaps between them and mucin deposit confirmed by staining with Alcian Blue at $\mathrm{pH} 2.5$ (Figures 2 and 3).

\section{Discussion}

$\mathrm{SB}$ is a generally benign dermatosis, part of the group of cutaneous mucinoses, with easy clinical and histopatho- logic diagnosis. SB was described by Buschke in 1902, and classified into 3 subtypes by Graff, in 1968: Type 1, associated with bacterial or viral infections; type 2 , associated with paraproteinemias; and type 3 , associated with $d i$ abetes mellitus. ${ }^{1,2}$

Type $1 \mathrm{SB}$ has a rapid onset and is usually preceded by fever. It is usually associated with infectious disease, particularly streptococcal infections, including: tonsillitis, pharyngitis, scarlet fever, cellulitis, otitis media, nephritis, rheumatic fever, and erysipelas, but also other infectious processes such as typhoid fever, impetigo,

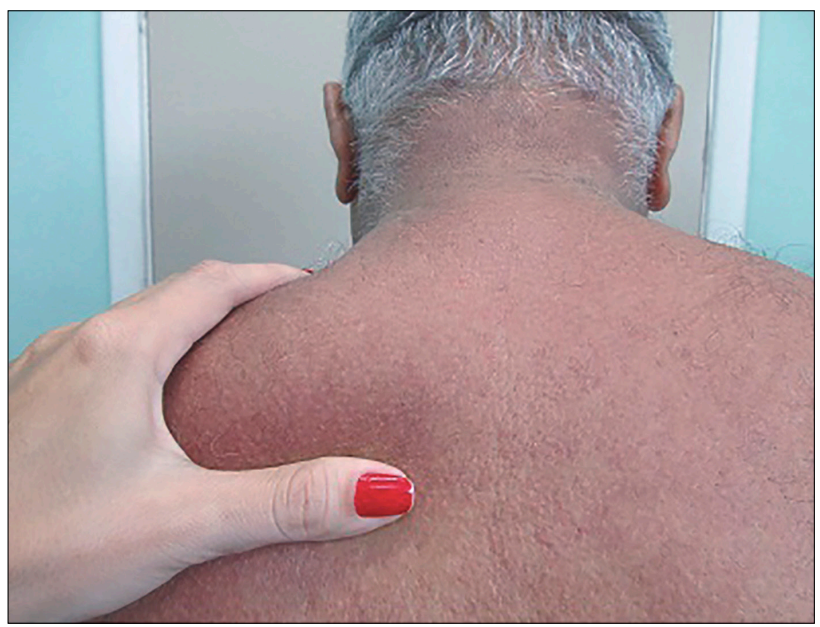

FIGURE 1 Erythema and induration of the neck and upper back. 


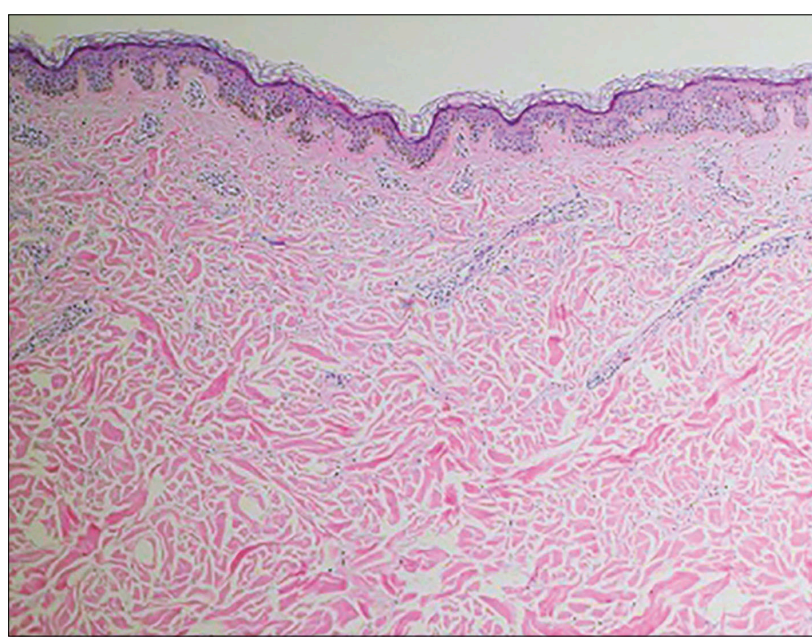

FIGURE 2 Thickened dermis, forming gaps between collagen bundles.

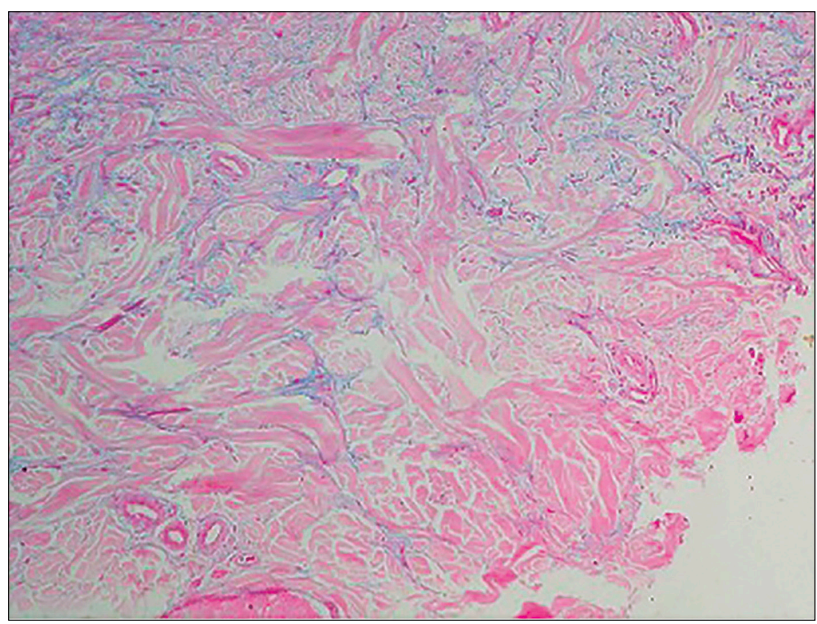

FIGURE 3 Material between thickened collagen bundles stained with Alcian blue at $\mathrm{pH} 2.5$, evidencing mucin deposits.

influenza, measles, parotiditis, CMV and HIV. It has better prognosis and is more prevalent in children and young adults. ${ }^{3,4}$

Type 2 is classically associated with paraproteinemias (monoclonal gammopathy), but there are also reports of an association with primary hyperparathyroidism, rheumatoid arthritis, amyloidosis and Sjogren's syndrome. It has a higher probability of chronic progression. ${ }^{1}$

Type $3 \mathrm{SB}$ is associated with diabetes mellitus (DM), both as type $1 \mathrm{DM}$ and type $2 \mathrm{DM}$. Patients most commonly reported in the literature are adult men with longstanding diabetes mellitus with glycemic control that is difficult to achieve, obesity and high blood pressure. Consequently, the DM has no tendency to spontaneous resolution. ${ }^{4,5}$
Pathogenesis is unknown, but the main mechanism of accumulation of matrix components appears to be related to abnormal gene expression of extracellular protein (collagen types I and III and fibronectin) in the skin. ${ }^{6}$ Other possible pathogenic factors would be: hyperinsulinemia, vascular damage, lymphatic obstruction, and streptococcal hypersensitivity.

Systemic manifestations are rare and include: cardiac, ocular, hepatosplenic, musculoskeletal and joint impairment; serositis, myositis and parotiditis; as well as involvement of the tongue, esophagus and pharynx. ${ }^{6}$

On histopathological examination, the epidermis has normal appearance and the dermis is thickened with broad collagen bundles and mucopolysaccharide deposits, visualized using special staining (Alcian blue at $\mathrm{pH}$ 2.5 to 4.0 , toluidine blue and colloidal iron). There is no increase in the number of fibroblasts. ${ }^{2}$ Mucin deposits can also be evidenced in other organs such as bone marrow, nerves, salivary glands, and heart.

Differential diagnosis includes scleroderma and scleromyxedema. Scleroderma is distinguished by acral skin involvement, Raynaud's phenomenon and typical fascies. Histopathological examination may reveal rectified epidermis, dermal sclerosis, and loss of appendages. Scleromyxedema, in turn, is characterized by confluent papules which gives a hardened appearance to the skin, with widespread deposition of mucin in the dermis, and fibrosis with irregular proliferation of fibroblasts. ${ }^{5,7}$

Several treatments have been proposed, such as topical, systemic and intralesional corticosteroids, immunosuppressives, and PUVA therapy ${ }^{1,4}$ Nevertheless, in most cases, the disease is self-limiting with spontaneous resolution. ${ }^{8}$ Its importance lies in the possibility of being a systemic marker of disease, such as difficult-to-control diabetes or paraproteinemias. The possibility of systemic involvement makes early diagnosis critical for proper treatment and better prognosis.

\section{Resumo}

Escleredema de Buschke associado a diabetes mellitus tipo 2 de difícil controle

Escleredema de Buschke (EB) é doença rara do tecido conjuntivo caracterizada por endurecimento difuso e não depressível da pele, principalmente nas regiões cervical, deltoideanas e dorso. Enquadrado no grupo das mucinoses cutâneas, tem etiologia desconhecida e associação com: infecções bacterianas ou virais, alterações hematológicas e diabetes mellitus. O exame histopatológico evidencia derme espessada com fibras colágenas calibrosas separadas por fendas que corre- 
spondem a depósito de mucopolissacárides, observados por colorações especiais. Diversos tratamentos são relatados na literatura sem resultados bem definidos. Descrevemos caso de EB em paciente com diabetes mellitus tipo 2.

Palavras-chave: escleredema do adulto, diabetes mellitus, dorso.

\section{References}

1. Gervini RL, Lecompte SM, Pineda RCB, Ruthner FG, Magnabosco EM, Silva LMC. Escleredema de Buschke: relato de dois casos. An bras Dermatol. 2002; 77(4):465-72.
2. Graff R. Discussion of scleredema adultorum. Arch Derm. 1968; 98:319-20.

3. Cron RQ, Swetter SM. Scleredema revisited. A poststreptococcal complication. Clin Pediatr (Phila). 1994; 33(10):606- 701

4. Dinato SL, Costa GL, Dinato MC, Sementilli A, Romiti N. Escleredema de Buschke associado diabetes melito tipo 2: relato de caso e revisão da literatura. Arq Bras Endocrinol Metabol. 2010; 54(9):852-5.

5. Pitarch G, Torrijos A, Martínez-Aparicio A, Vilata JJ, Fortea JM. Escleredema de Buschke associado a diabetes mellitus. Estudio de cuatro casos. Actas Dermosifiliogr. 2005; 96(1):46-9.

6. Meguerditchian C, Jacquet P, Béliard S, Benderitter T, Valéro R, Carsuzza F, et al. Scleredema adultorum of Buschke: an under recognized skin complication of diabetes. Diabetes Metab. 2006; 32(5 Pt 1):481-4

7. Sampaio SAP, Rivitti EA. Mucinose e mucopolissacaridoses. Dermatologia. 3.ed. São Paulo: Artes Médicas, 2008. P.933-44

8. Bowen AR, Smith L, Zone JJ. Scleredema adultorum of Buschke treated with radiation. Arch Dermatol. 2003; 139(6):780-4 